\title{
IAMJ
}

INTERNATIONAL

AYURVEDIC

MEDICAL JOURNAL

\section{A REVIEW OF UNIQUE PANCHAKARMA MODALITY- SARVANGADHARA}

\author{
Minu Yadav', Gopesh Mangal² \\ ${ }^{1}$ MD Scholar, PG Dept. of Panchkarma, National Institute of Ayurveda, Jaipur, Rajasthan, India \\ ${ }^{2}$ Associate Professor, PG Dept. of Panchkarma, National Institute of Ayurveda, Jaipur, Rajasthan, India
}

Corresponding Author: minuyadav12@gmail.com

\section{https://doi.org/10.46607/iamj2909102021}

(Published Online: October 2021)

Open Access

(C) International Ayurvedic Medical Journal, India 2021

Article Received: 26/09//2021 - Peer Reviewed: 06/10/2021 - Accepted for Publication: 07/10/2021

\section{Check for updates}

\begin{abstract}
The classical Ayurvedic texts are endowed with unique treatment modalities. Panchakarma procedures form an important backbone in Ayurvedic treatment. One of the Panchakarma therapies is the Sarvangadhara. It is also known as Kayaseka, Pizhichil, Seka and Dhara. It is classified under Sagni Sweda as Parisheka Swedana by Acharya Charaka whereas Acharya Sushruta mentions it under Drava Sweda. It is a special Bahir-Parimarjana therapy where it does both Snehana and Swedana simultaneously. In this procedure medicated liquid (oil/Kwatha/Takra) is poured over the body in form of Dhara or stream for a stipulated period. The present study aims to review the procedure of Sarvangadhara through the study of various Ayurvedic and modern literature, published research papers, and textbooks. The procedure induces sweating and relieves stiffness, heaviness and coldness in the body. It is very helpful in Vata-Pradhana diseases like neurological diseases and degenerative disorders. Parisheka Swedana is mentioned as Samanya-Chikitsa of Vata-Vyadhi. It is widely practised in Ankylosing spondylosis and the chronic stage of osteoarthritis condition. The medicines are changed based on the conditions like TakraDhara is adopted in cases of psoriasis and Dhanyamla-Dhara in obesity.

In the present article, an attempt has been made to review the procedure and benefits of Sarvangadhara as a Panchakarma therapy in the treatment of various diseases.
\end{abstract}

Keywords: Sarvangadhara, Parishek, Pizhichil, Seka, Dhara, Swedana 


\section{INTRODUCTION}

The main treatment principle in Ayurveda is based on the Tridosha theory. The balance of these Dosha brings about a sense of well-being in the body. The Vata-Dosha being the powerful causes eighty diseases (eighty Vataja-Nanatmaja Vyadhi). ${ }^{1}$ The classical Ayurvedic texts are endowed with unique procedures. Panchakarma which is one of the essential therapies of Shodhana forms the backbone of Ayurvedic treatment. The procedures like Snehana and Swedana are highly innovative practices in the mainstream of Ayurveda. One such procedure called Sarvangadhara provides twin benefits of Snehana (if oil is used) and Swedana. It is an effective procedure, which is also called Parishek, Pizhichil, Kaya-Seka and Dhara. It is mentioned as Samanya-Chikitsa of Vata-Vyadhi wherein a medicated liquid (oil/Kwath/Takra) is showered over the body for a stipulated time frame. ${ }^{2}$ Materials and Method-

The study of various Ayurvedic and modern texts has been done. References regarding Sarvangadhara is collected from various textbooks, published research papers, previous work done, and its probable mode of action is explained in the present study.

\section{Sarvangadhara}

Sarvangadhara is made from two words- Sarvanga means all over the body and Dhara represents stream while the word Pizhichil (Malayalam word) means squeezing. In this process, a continuous stream of medicated oil/Kwath/liquid is poured over the body which is simultaneously followed with a mild massage. This process provides a sudation effect all over the body. It is considered under Parishek Swedana as per Charaka whereas Sushruta considers it under Drava Sweda. The liquid is poured from a height of 12 Angula (9 inches). There are varieties of Sarvangadhara based on the liquid medium used eg. SnehaDhara (oil/lipids), Takra-Dhara (buttermilk), Ksheera-Dhara (medicated milk), Gomutra (cow urine), Kwath-Parisheka (decoction) and Kanji. It holds immense benefits due to its dual function of Snehana and Swedana. It is practised in diseases where there is the involvement of the whole body, Sarvangavata, Sarvanga Kushtha, Sarvanga Shopha etc to name a few.

The procedure of Sarvangadhara- the entire process is categorized into 3 parts-

1. Poorva-Karma (pre-operative procedure) -

- Collection of essential material for Sarvangadhara

- $\quad$ Preparation of the patient

- $\quad$ Preparation of the medicated liquid Materials required for the procedure include-

- Medicated liquid- Taila/Takra/Ksheera- 3-5 litres

- Gas stove

- Cloth pieces- 4 (18" x 18")

- Masseurs - 5 (2 on each side of upper and lower limbs)

- Iron vessel - 6 (2 for heating the oil and 2 for keeping and 2 for collecting it)

- Soft cotton towel- 2

Table 1: Showing the medicated liquid used based on various conditions ${ }^{3}$

\begin{tabular}{|l|l|}
\hline Condition & Medicated liquid used \\
\hline Vata Pradhan Avastha & Dhanwantara Taila, Mahanarayan Taila \\
\hline Pitta Pradhan Avastha & Kshera Bala Taila, Chandan-Bala-Lakshadi Taila \\
\hline Kapha Pradhan Avastha & Sahacharadi Taila \\
\hline
\end{tabular}

Pre-preparation - heat the oil in a double boiler and place it in the vessels kept on the Droni.

Preparation of the patient- The patient is advised to evacuate his natural urges and is examined for vitals before the start of the procedure. The Rogi-Bala and
Roga-Bala are also assessed, and the patient is made to sit on the Droni.

The patient wearing minimum clothing is advised to be seated with leg extended over the table. Abhyanga is performed firstly on the vertex, ear and feet. Later 
Sarvanga Abhyanga is to be done with the prescribed medicated oil for about 10 minutes. The eyes of the patient are covered with thick cotton pads and Amalaki Kalka Talam is kept over the vertex.

The Sarvangadhara can be performed above the neck based on the severity and nature of the disease.

Pradhana Karma (main procedure)- the patient after Abhyanga is advised to sit over the Droni. The cloth pieces are dipped in the hot medicated liquid (temperature between $42-45^{\circ} \mathrm{C}$ ). Two attendants are placed on either side of the patient such that two attendants pour the oil from the shoulder to palm and the other two pour the oil from the root of the thigh to feet. The soaked cotton pieces are squeezed over the body such that the medicated liquid should flow in a uniform stream from the thumb facing downwards in Anuloma direction from a height of 12 Angula (9 inches). In some cases, a specialised Varshulika (watering vessel having holes in the bottom) or Kindi (tea kettle like pot) is used for the purpose of Sarvangadhara. Nowadays, automatic machines are used for sprinkling medicated liquid over the body. The masseurs after sprinkling the oil with one hand should simultaneously massage with the other hand. The oil flowing out is collected in a vessel and used after reheating. The process is repeated in all seven postures.

\section{Paschata Karma (Post-operative procedure)-}

- Abhyanga is done again.

- Excessive oil is removed using napkin or cotton towel.

- The patient is advised to keep himself covered properly and avoid exposure to breeze and sunlight.

- The patient is advised to take a warm water bath after 2-3 hrs.

- A freshly prepared light diet is to be taken.

- The patient is refrained from indulging in AstaMaha-Dosha Kara Bhava (eight factors to be avoided).

- The patient is advised to take Gandharvasthyadi Kwatha in the dose of $20-40 \mathrm{ml}$ twice a day as it helps in the easy evacuation of Dosha accumulated in the Koshtha.

\section{Change of oil/medicated liquid-}

- $\quad$ Freshly prepared Kwath, Ksheera, Takra and Gomutra should be taken.

- Use half of the oil ( 2.5 - 3ltr) in the first three days and the oil is changed on the $4^{\text {th }}$ day.

- The oil at the end of the $3^{\text {rd }}$ day and $6^{\text {th }}$ day is mixed and used on the $7^{\text {th }}$ day.

Duration of the procedure- 45 minutes to 1 hour for 7-21 days.

Table 2: Showing the duration of Sarvangadhara based on the condition ${ }^{4}$.

\begin{tabular}{|l|l|}
\hline Based on condition & Duration \\
\hline In Vata Vyadhi & 5 Nadika $(\sim 2$ hours $)$ \\
\hline In Vata-Kaphaja Disorders & $\sim 1$ hour \\
\hline General indication & $33 / 4$ Nadika $\left(\sim 1 \frac{1}{2}\right.$ hours $)$ or till the appearance of sweat \\
\hline
\end{tabular}

\section{Indications ${ }^{5}$ -}

- Sarvangavata condition

- Pakshaghata (hemiplegia)

- Parshava-Prishta-Kati Graha, Ankylosing spondylitis

- Apatantraka (neurological disorder associated with seizures)

- Vatavyadhi

- Muscle wasting in Rheumatoid arthritis

- Gulma
- Udavarta

- Moodha-Vata (obstructed Vayu)

- Kampa (tremors and chorea)

- The patient indicated for Swedana procedure Contraindications-

- Madhumeha

- Paittika Prakriti

- Udara roga

- Ajeerna condition 
- Other patients contraindicated for Swedana procedure

\section{Precautions-}

- The temperature of the medicated liquid should be checked before the start of the main procedure.

- The stream should not be poured over a single place for too long as it may lead to burning.

- The Sarvangadhara process should be performed in a non-airy room.

- The temperature of the medicated liquid should be constant throughout the procedure to avoid temperature variations and provide even sudation.

- The stream should be uniform and continuous.

- The height of 12 Angula must be maintained throughout the procedure.

\section{Complications-}

- There are chances of skin burns when excessive hot medicated liquid is poured. The procedure must be stopped and managed accordingly.

- Due to excessive and long duration sudation, there are chances of vaso-dilation which may result in raised blood pressure.

- Excessive sudation may cause giddiness and fainting.

- Direct exposure to cold temperature after sudation may cause fever, headache and the common cold.

\section{DISCUSSION}

Sarvangdhara or Pizhichil is an important part of Swedana procedure. It is mentioned under the variety of Drava Sweda. Based on the liquid media used, it can be of Ruksha and Snigdha nature. When the liquid media has Snigdha properties, it does both Snehana and Swedana whereas on having Ruksha properties, it does Swedana along with Rukshana.

As per Dharakalp, it is mentioned that Sarvangadhara brings Dridta (firmness) and Vrishta (vigour) in the body. It increases the Agni (digestive fire), Oja (immunity) and enhances the complexion of the body. Regular practice of Sarvangadhara delays old age prevents fractures and dislocation and alleviates vitiated Vata Dosha. It results in stability of Indriya and boosts its function. When the Sarvangadhara is done with lukewarm medicated liquid, it pacifies all the aggravated Dosha. ${ }^{6}$

Sarvangadhara is also indicated in gynaecological disorders and females undergoing difficult labour. A case of Apatantraka (neurological disorder associated with seizures) in a full-term pregnant woman was recorded wherein Pizhichil was performed for 24 hours and another where it was performed for 36 hours continuously based on the treatment principle of Tailadronisayana (lying in table specifically designed for the purpose) in Apantantraka. The second case was saved, and the lady delivered a child, but the first case was a stillbirth though the woman survived. ${ }^{7}$

\section{Probable mode of action-}

Sarvangadhara works on the similar principle of Swedana process. Based on the quality of the drug used, it does Snehana or Rukshana. It is effective in Vata Vyadhi, Pakshaghat, Apatantraka, Stambha (stiffness), ankylosing spondylitis and other neurological conditions. Just like Swedana therapy, Sarvangadhara acts due to its Ushna and Teekshna properties. The application of lukewarm/ mild hot medicated liquid increases the metabolic rate which causes vasodilation of the blood vessels. This vasodilation opens the smaller channels and increases the peripheral circulation. The pores in the skin open leading to an elimination of waste products through sweat. The increased circulation promotes better absorption of medicated liquid into the body. Dhanyamla Sarvangadhara is effective obesity treatment. One of the factors can be the Rukshana action brought about by Dhanyamla. ${ }^{8}$ Other factors can be assumed that the drug when poured from a height creates an impact force that liquefies the Medo Dhatu and removes the adhered adipose tissue. Thus, continuous use of Dhanyamla Sarvangadhara brings about Dridta and helps in obesity. The four Tiryak Dhamani in the body divide into hundred and thousand times and become innumerable. These cover the body like a network and their openings are attached to Roma Kupa (skin pores). Through these Roma Kupa, the Veerya of Abhyanga, Parishek, Avagaha, Alepa enter the body after undergoing Paka by Bhrajaka Pitta in the skin. The Bhrajaka Pitta present in the skin gets stimulated and helps in transdermal 
absorption of the medicated liquid..$^{9,10}$ The medicated liquid absorbed through the skin into the blood vessels shows systemic results all over the body. A probable hypothesis can be made for the action of Sarvangadhara. The medicated liquid is poured from a height of 12 Angula. The liquid falling over the body surface creates a ripple effect. An impact force is generated which transfers into the deeper tissues. This stimulus thus created, stimulates the sympathetic nervous system. The fibres from the sympathetic nervous system innervate the tissues in every organ system and provide physiological regulation over diverse body processes. The morbid Dosha then move from Shakha to Koshtha. The Dosha accumulated in the Koshtha is gradually removed from the Koshtha by regular use of Gandharvahastadi Kwatha. It pacifies Vata, enhances digestive power and does Mala-Shodhana. ${ }^{11}$ This helps in pacifying and eliminating morbid deep-seated Dosha.

\section{CONCLUSION}

Sarvangadhara is an important therapeutic measure of Panchakarma which is effective in various disorders. It is a complete therapy as it provides multiple health benefits. Based on the medicated liquid used, it does Snehana and Rukshana along with Swedana. It is used in Vataja and Vata-Kaphaja disorders, neurological disorders, gynaecological disorders and difficult labour. Further research needs to be carried out to explore the versatile and systemic results of the therapy.

\section{REFERENCES}

1. Charaka Samhita, Sutra Sthana Maharogaadhyaya 20/11. Available from: http://niimh.nic.in/ebooks/echarak. [Last accessed on 2021 March 18].

2. Dr Brahmanand Tripathi, Astanga Hrdayam of Srimadvagbhata, Chaukhamba Sanskrit pratisthan, New Delhi, reprint edition 2017, Sutra Sthana Doshopakramaneeya Adhyaya, 13/2, Pg. no. 185.

3. Prof. Radheshayam Sharma, Dr Gopesh Mangal, Dr Gunjan Garg, Ayurvediya Panchakarma Chikitsa Vigyan, Jagdish Sanskrit Pustakalaya Jaipur, Second edition, 2019, Swedana Karma, Pg. no. 122.

4. Vaidya Haridas Sridhar Kasture, Ayurvediya Panchakarma Vigyan, Shri Baidyanath Ayurveda Bhavan
Limited, Allahabad, $17^{\text {th }}$ edition, 2016, Sweda Vigyan, Pg. no. 163.

5. Dr. S. Sharma, Dr. H. L. Sharma, Dharakalp, Chaukhamba Orientalia, New Delhi, Shloka no. 27

6. Dr. S. Sharma, Dr. H. L. Sharma, Dharakalp, Chaukhamba Orientalia, New Delhi, Shloka no. 2

7. Bindu. K. K., Mrudula Vinayak Joshi, Uma Karthik, CONTRIBUTION OF KERALA TO AYURVEDIC LITERATURE IN PANCHAKARMA WITH SPECIAL REFERENCE TO PANCHAKARMAM ATHAVA SODHANA CHIKITSA: A REVIEW, International Journal of Research in Ayurveda and phar$\begin{array}{llll}\text { macy } & 2018, & 9 & \text { (5):30-34 }\end{array}$ http://dx.doi.org/10.7897/2277-4343.095150

8. Vandana, Alok Kumar Srivastava, Meenakshi Gusain, Priyanka. Efficacy of Dhanyamla Sarvanga Dhara in the Management of Obesity: An Analytical Review. International Journal of Ayurveda and Pharma Research. 2018;6(6):81-84.

9. Sushruta Samhita, Shaareer Sthana Dhamani Vyakaran Shaareer 9/9. Available from: HTTP:// niimh.nic.in/ebooks/esushruta. [Last accessed on 2021 Mar 18].

10. Sushruta Samhita, Sutra Sthana Vranaprashanaadhyaaya 21/10. Available from: http:// niimh.nic.in/ebooks/esushruta. [Last accessed on 2021 Mar 18]. Su. Su 21/10

11. Dr Pulak Kanti Kar, Principles and Practice of Panchakarma, Chaukhamba Sanskrit Pratishthan Delhi, first edition 2013, Svedana, Pg. no. 249.

\section{Source of Support: Nil Conflict of Interest: None Declared}

How to cite this URL: Minu Yadav et al: A Review Of Unique Panchakarma Modality- Sarvangadhara. International Ayurvedic Medical Journal \{online\} 2021 \{cited October 2021\} Available from: http://www.iamj.in/posts/images/upload/2481_2485.pdf 